
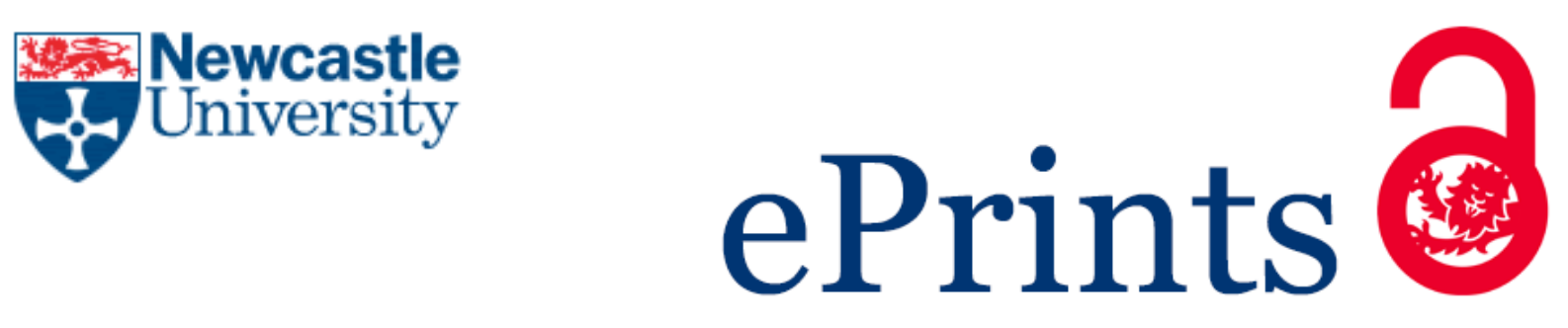

Shaw Robert.

Pushed to the Margins of the City: The Urban Night as a Timespace of Protest at Nuit Debout, Paris.

Political Geography 2017, 59, 117-125.

\title{
Copyright:
}

(C) 2017. This manuscript version is made available under the CC-BY-NC-ND 4.0 license

DOI link to article:

https://doi.org/10.1016/i.polgeo.2017.05.006

Date deposited:

$17 / 05 / 2017$

Embargo release date:

30 May 2019

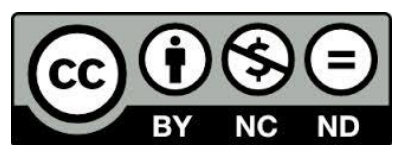

This work is licensed under a

Creative Commons Attribution-NonCommercial-NoDerivatives 4.0 International licence 


\title{
Pushed to the Margins of the City: The Urban Night as a Timespace of Protest at Nuit Debout, Paris
}

Final Pre-Publication version; for full article see 10.1016/j.polgeo.2017.05.006

\begin{abstract}
Geographers studying protest movements have brought attention to the social and spatial contexts in which political action is constituted. As the legal right to protest has become more and more restricted in many Western, activists have had to seek new times and spaces for protest, with protest camps having risen alongside the anti-austerity movement since 2011. The ongoing Nuit Debout protests in Paris have turned explicitly to night, drawing on experience of previous protests to colonise this timespace on a recurring basis, laying to claim to the night as a moment for protest. This paper therefore uses the case of Nuit Debout to consider more widely how night shapes (urban) protest movements. I argue that the move to the night might be seen as an attempt to find a timespace in which a more open and creative politics is possible, strategically responding to the reduction in the freedom to protest in the more heavily surveyed day. I explore how the specific characteristics of night have both facilitated innovation at Nuit Debout and other sites, but also the restrictions that night has brought. More broadly, this helps us understand the changing dynamics of urban spaces and rhythms as night-time activity intensifies.
\end{abstract}

Keywords: Night, protest, assembling, rhythm, Paris, public space

Dr Robert Shaw, Newcastle University, Robert.shaw2@ncl.ac.uk, 


\section{Pushed to the Margins of the City: The Urban Night as a Timespace of Protest at Nuit Debout, Paris}

"Revolution sometimes happens because everyone refuses to go home" (Butler, 2015 p.98)

On March $31^{\text {st }} 2016,390,000$ people gathered in Paris's Place de la République to protest against the 'Loi Travail', a set of proposed changes to France's 'Labour Code', which consists of the laws and practices that provide French workers with significantly more rights than those in many other European countries, including the symbolically significant 35 hour limit to the working week. The protests began as many others do during the day, and continued through the afternoon. As night fell, however, the protestors did not go home. Speeches and debates continued, giving way as night progressed to more relaxed discussions, drinking, partying and eventually sleeping. When morning came the majority left, with a small number of protestors remaining to maintain the temporary structures that had been built in la République. The next night, at $6 \mathrm{pm}$ on what the protestors called 'Mars $32^{\mathrm{em}}$ ("March $32^{\text {nd") }}$ ), many returned, to spend another night debating, discussing and protesting. The protestors hadn't gone home; the Nuit Debout movement was born. Following this, Nuit Debout took on a new form of nightly recurring protests, with events beginning in the late afternoon and continuing until roughly midnight. Further protests spread to other French cities, notably Grenoble and Lyon, as well as to other cities in Europe and the Francophone world, though outside of France with much less impact. The protests persisted with regularity until the summer of 2016, before transforming into a more infrequent series of events, coordinated around an online presence. Nuit Debout, translating roughly as 'through the night' but perhaps more evocatively as 'all night long', is a movement inspired by the protest camps of Indignados in Spain and Occupy in the Anglophone world, and alongside these it forms part of a group of activist and political movements across the world that have emerged in the wake of the Arab Spring and anti-austerity protests (Feigenbaum et al., 2013). While Nuit Debout is the first of these protests to make its nocturnality explicit, all these protests are linked by the new ways in which they have continued into the night. In so doing, then night and specifically the urban night emerges as a newly contested timespace for social movements. As such, it offers both opportunities for these movements, and presents new challenges.

In this paper, I want to add to the literature which has begun to explore the embodied experiences of these movements (Bolton et al., 2016; Halvorsen, 2015; Juris, 2012) by looking at the role that the night has played for Nuit Debout, and other similar protest movements. In the same way that geographers have studied the role of place in producing spaces of protest (Massey, 1995), this paper engages with night as both a resource and a barrier for action, which shapes the nature of protest activity but which also may itself be shaped the presence of protestors. In so doing, my argument is that as night is a timespace at the edge of the contemporary city, protestors in these movements have been able to make claims over it in ways that they are no longer able to in the increasingly restricted and controlled day. This has facilitated the production of new time-spaces for democratic debate and participation, facilitating the sort of creativity of protest that the post-2011 movements have sought, with greater or lesser success. This article begins with an exploration of the history of night and protest movements, exploring how recent protest movements differ in their use of night from those that had gone before. I will also explore how night sits at the edge of contemporary urbanism, and expand upon my description of it as an edgespace. Through participant observation, photography and a small number of interviews at Nuit Debout in May 2016, I then document the ways in which night has been used as a resource by protestors. I focus on three key themes: disruption; conviviality and cover; presence and visibility. In this research, Nuit Debout acts as an interesting case study, with its repeating nocturnal activities standing as a roughly 6 -month 
experimentation in a particular form of urban protest movement. I argue that this allows us to explore more broadly how contemporary protests are finding power in pushing at the edge of what it means to inhabit the city, in order to carve out spaces in public discourse.

\section{The Urban Night, Protest Camps and Not Going Home}

Geographers studying protest and activism have sought to show how the places and spaces of protest shape the emergent political activity. In a seminal paper, Massey argues that "spatiality can be a key moment in the constitution of political subjectivities and collectivities" (1995p.285). She argues that by bringing a focus on spatiality, geographers can ground understandings of emergent socio-political identities through their empirical contexts and histories. The specific places in which activist and protest movements form and the ways that they transform and are transformed by these places are therefore central to the ways both in which they contest power, and in which the protestors construct their own identities. In their writing on 'autonomous geographies', Chatterton and Pickerill identify protest spaces as "those spaces where there is a questioning of the laws and social norms of society and a creative desire to constitute non-capitalist, collective forms of politics, identity, and citizenship (2006p.730)." Perhaps unsurprisingly, geographers have been particularly attracted to study of protests about the nature of access to specific places or to public space more generally, as seen in the focus on various 'Right to the City' movements (Mitchell, 2003) or contestations over key urban sites as part of regeneration, redevelopment or gentrification processes (Smith, 2002; Uysal, 2012). A point I want to develop here is the claim that the production of protest spaces requires a "spatio-temporal strategy" (Pickerill \& Chatterton, 2006p.735). While such strategies may be located narrowly in a specific place, they are always connected with broader networks, and the very act of using strategies to produce protest spaces that imagine possible futures is a cosmopolitan one, oriented towards futures and towards other places. In this paper, by bringing out the role of night in protest spaces, I look to focus a little more on the intersection of the spatial and the temporal that Pickerill and Chatterton's wording implies, producing a fuller picture of the strategies involved in creating protest spaces.

Historically, night has been seen as a politically dangerous timespace. Prior to the spread of public artificial lighting, the state typically viewed nocturnal activity with suspicion. Curfews were common, and the church and state engaged in a direct form of what Foucault calls 'sovereign power' (Foucault, 1982), with harsh physical punishments applied to those who attempted to evade the night-watch (Beaumont, 2015). Gradually through the nineteenth century, such an approach to governing the night became impractical. As a variety of accounts by historians have explored (Baldwin, 2012; Schivelbusch, 1988; Schlör, 1998), new forms of leisure, work and capital emerged in the night-time city alongside the development of technologies of artificial lighting and heating. From incessant factories to night-time entertainment, lit and active parts of the city were gradually turned over to the public. Such processes increased through the twenty-first century and beyond (Crary, 2013; Gwiazdzinski, 2005; Melbin, 1987), such that some writers now speak of an era of '24/7'. The night, it is argued, has become safer, tamer and better-understood, though later work - such as that of Gwiazdzinski and Crary - has been subtle in its analysis, showing intersecting temporalities. Indeed, social science work has increasingly shown the variety of ways in which night is used in the contemporary city (Edensor, 2015). Despite becoming more integrated into the city, however, night remains a timespace at the border of urban life. As activity expands in certain ways, nonetheless many of the characteristics of urban life that we would take for granted in the day have gone services do not run, our networks of friends and acquaintances are not accessible, transport becomes more difficult, and so forth. On a global scale, night is becoming less distinct from day, being significantly incorporated into the same socio-economic systems as daytime: this might be 
described as part of the spatio-temporal expansion of capital (Castree, 2009). However, night remains a time outside of normal rhythms, and a time in which many people are uncomfortable using public space. Night, as such, has not disappeared, but has fragmented with activity and 'day' appearing in certain places, but quiet and darkness remaining in many.

It's worth pointing out here that the object we describe at night is itself varied, contested and multiple. Analytically, we can identify two core components of night. The first of these can be (somewhat clumsily) called the 'biogeoastronomical' night, that is, the intersection of biology, geography and astronomy. From this, we get the latitude-differentiated seasonal and circadian rhythms of light and dark but also the association of these with sleep or rest. Crucially, this element of night brings with it, to a greater or lesser extent, darkness and artificial illumination, which shape our relationships with place (Edensor, 2013, 2015). The interplay of darkness and artificial illumination creates a thicker, more complex urban landscape in which shadows grow and move, some spaces become hidden but moments of city are foregrounded. We lose our capacity to differentiate between things (Edensor, 2015; Morris, 2011); we lose even the certainty of the boundary around own bodies (Shaw, 2015). In understanding night, we must thus understand a timespace in which we are more open, more uncertain, more tentative and perhaps more vulnerable. Second, the 'sociorhythmic' night refers to the closure or reduction in multiple different services, practices, infrastructures and activities. Here, night is created not by one or two practices going into 'night-mode' - we can easily imagine spaces (e.g. nightclubs) which are busier at night than day - but by the intersection of multiple rhythms, the 'polyphony' to borrow Lefebvre's phrasing (2004), which together produce a timespace of reduced activity in most spaces, even in large built-up areas and even in spaces which might not be experiencing the darkness of the biogeoastronomical night. In other words, recognising the presence of a 'socio-rhythmic' night helps us identify that features of 'the night', such as reduced public services, increased representation of maintenance, repair and cleaning work, and a shift in city-life towards leisure and away from work, can exist without the darkness of night falling. That said, they of course interact more than they are separate: nocturnal isolation, for example, can be associated with a mixture of fear of injury or attack when walking in darkness, alongside a reduced range of activities that it is possible to attend (Green et al., 2015). In understanding social rhythms and night there is clearly more to say (see Edensor, 2012b for a fuller introduction), but the key point in this diversion here is that night can be understood as both a social and natural phenomenon. It is important to further note that, while night itself is differentiated from day, the experience of night is also further distinguished by class, gender, ethnicity, mobility, age and other forms of social stratification, as well their intersections for any one person.

As a timespace for protest, the night has been most readily associated with two movements. I explore these in order to pull out some of the ways that night has been used in protest movements to-date. The 'Take Back the Night' (TBTN) protests that have formed part of the feminist movement since the mid-1970s. These protests have sought to challenge violence, sexual violence and associated repression of women's mobilities by encouraging women to come onto the street at night, typically in protest marches. The aim of these protests has been to highlight women's oppression through visibly congregating in a timespace that it is deemed improper for women to be in. Night is a time which "promises harm to women", whereby for a woman to be present is "not only to risk abuse, but also - according to the values of male domination - to ask for it" (Dworkin, 1993p13). At night, many women "develop individual mental maps of places where they fear assault", avoiding walking alone, and visiting certain spaces or places (Valentine, 1989p385). These personal fears are reinforced by narratives of 'staying safe' often expressed by figures of authority, which have placed responsibility on women to avoid public space at night, rather than seeking to 
tackle the conditions which have produced this fear and danger. The aim of TBTN has been to arrange protest marches of hundreds or thousands of women inhabiting the 'wrong place'. The gendered and sexual politics of TBTN has not been unquestioned. The movement's focus on 'stranger' sexual assault, prostitution and other forms of 'vice' (Hubbard et al., 2015 p.514) has led to arguments that it has done little to criticize the discourses that state that women should not also desire using the city at night for sex or drinking, though equally discussions can be found that compare its sexual politics favourably to other movements such as 2013's 'SlutWalks' (Dow et al., 2014). Further critiques have focused on TBTN's lack of intersectional awareness, particularly in relation to race, though again these critiques have also themselves been contested (Mackay, 2014). The underlying point here is that TBTN and similar movements have not discovered or presented a form of night that is straight-forwardly open to all. Nevertheless, TBTN pre-empts the post-2011 movements' use of corporeal presence as a form of protest: "We must use our bodies to say "Enough": we must form a barricade with our bodies, but the barricade must move... we must use our collective strength and passion and endurance to take back this night and every night" (Dworkin, 1993p.17). In other words, and despite a somewhat limited purview, TBTN marches have laid claim to public space at night through the physical presence of bodies, and this claiming of space and discourse through presence at night is something which later movements have picked up.

The second major form of protest that has inhabited night has been the protest camp. The first protest camps date to the 1960s and 70s, though as a tool of protest they did not become widespread until after 2011. One of the largest and longest running 'early' camps was the Greenham Common women's peace camp, this being perhaps the most notable and impactful protest camp (Cresswell, 1994). The camp was located outside the Greenham Common air-force base in England, at which nuclear weapons were being stored. At these camps, the presence of women living on the site was an attempt to gain legitimacy by emphasising the threat that the weapons posed for daily life and the future. By moving to and living in spaces for extended periods of time - Greenham operated for 19 years - the protestors attempted to perform both strength and power, in face of state violence, as well as significant sexist reporting and discourse (Cresswell, 1994). By forming a camp rather than a day-time protest or series of protests, the Greenham Common movement attempted to overcome the perceived 'weakness' of a female-only protest that misogynist popular discourse sought to portray. In particular, it was only at night that the camp was strictly woman-only (Harford et al., 1984) making the night-time a key moment for the camp's identity. Of course, this did not produce a night that was purely safe or secure. The night at Greenham Common was often uncomfortable (p.72); police raids or bulldozing of parts of the site often occurred at night (Harford \& Hopkins, 1984 p.27; Junor, 1995 p.20). Night was thus both a time of danger, but also the moment in which Greenham and other peace camps affirmed their unique characteristics. Like Greenham, many (though not all) protest camps took place outside of an urban setting, with attempts to create peace camps in urban areas more readily thwarted. Other camps, such as those which formed part of anti-globalisation protests at meetings of global leaders, were temporary (Routledge, 2000). Many of these camps took place in a largely pre-digital era before the increased telecommunications technology of mobile phones and the internet, the rural night of the peace camps was significantly more isolated, more 'nocturnal' than both the urban night at the time, and the rural night today. So in Greenham and other protest camps, it was the relative freedom and autonomy of the rural night that was the key advantage of that timespace though as noted, night here was both an important asset and a time of danger and discomfort.

This broader interplay of on the one hand freedom and autonomy and on the other hand uncertainty and danger can be said to characterize the protest camp movement that has grown since 2011. Where positive, camps can be "spaces where people come together to imagine 
alternative worlds and articulate contentious politics, often in confrontation with the state" (Feigenbaum et al., 2013 p.2). In practice, protest camps have had many forms. Most notably, these protest have included several from the Arab Spring and in particular the occupation of Tahir Square; the Indignados movement in Spain; and the Occupy movement in the Anglophone world. Several reasons have been given for their emergence, but one key factor has been that they have allowed protestors to (briefly) claim and gain ownership of public space to raise an issue, making an argument or group visible for as long as is possible. As geographers and other social scientists have explored, however, the rights to do this - the ability to claim public space, to hold protests outside seats of power and to influence public debate through this mingling in public space - has been eroded through the neoliberalisation of public space since the 1990s (Amin, 2008; Mitchell, 2003, 2016; Roberts, 2008). The protest camp is a direct response to this changing public space. Like Greenham Common and other earlier protest camps, the urban protest camps since 2011 are distinguished from other protest sites by "the sustained physical and emotional labour that goes into building and maintaining the site as simultaneously a base for political action and a space for daily life" (Feigenbaum et al., 2013 p.2). In other words, protest camps incorporate into them various forms of social re-production that are necessary for living. As such these protests have all been marked by large numbers of people staying in place through the night. By camping, cooking and inhabiting urban spaces at night, protestors have been claiming their right to protest, their right to public space, and the strength of their commitment. At the same time, the protest camp has been itself a contested site. To take one reflection on the Occupy site in London:

From the start we have had numerous internal tensions and problems. This includes the (re)creation of patriarchal relations in our autonomous spaces; numerous hierarchies based on experience, skills and confidence and incidents of violence, abuse and disruption, violating our 'safer space' policy (Halvorsen, 2012p.429).

In other words, protest camps are not inherently transformative sites; rather, the production of autonomous and transformative spaces is what Halvorsen characterizes as a continuous process. Still, there is I would argue - and drawing on the Butler quote which opens this article - an inherent power in the mass collection of bodies, particularly where (as in public space at night) these are in the 'wrong space'. As she elaborates, "asserting that a group of people is still existing, taking-up space and obdurately living is already an expressive action... the bodies assembled say we are not disposable, even if we stand silently" (2015p.18). While night is a key part of this - and arguably a defining part of it, for it is in staying during the night that these movements have differed from those before them - the specific role of the urban night in these new protest movements has not been explored.

This is clearly not a complete history of night and protest. Most obviously, night has also long been a time for direct action, in which reduced surveillance becomes a key resource for activists (Graeber, 2009). Other protests - strikes, marches and other events - will also have extended into the night. However, in TBTN and the protest camps, night is put in the centre of the protest in ways that does not happen elsewhere. In other words in these events, night like place has operated as both a resource and a barrier for action, a dimension which shapes the nature of protest activity but which also may itself be shaped. With the rise of the protest camp post-2011 (Feigenbaum et. al., 2013), this role of the urban night in protest is enhanced. Drawing from the understanding of night as a peripheral timespace in the city, with twofold sets of characteristics (the socio-rhythmic night and the biogeoastronomical night), I want to explore how these movements have taken to the borders of urban life in order to construct new spaces for protest, conversation and democracy. In the case of 
Nuit Debout, the role of night is intentionally brought to the front, and as such these protests offer a unique opportunity to explore how the characteristics of the urban night as a timespace have helped facilitate these aims. The following is based upon a three night visit to Nuit Debout, during which I conducted around 16 hours of participant observation, two transcribed interviews with activists and a series of ad hoc conversations with others around the site. In addition to this, the material draws from the publications produced by the Nuit Debout movement, distributed through their social media and website. While the empirical material as such is exploratory, it helps illustrate and explore the arguments which are developed in relation to the wider literature and trends in protest camps since 2011.

\section{At Nuit Debout}

The Nuit Debout site, at the time of my participant observation, filled around half of La République. From mid-afternoon onwards, the site would gradually become busier. The first 'commissions' - Nuit Debout's units of action - would start with discussions at around 14:00 or 15:00, typically with discussions based on groups seated in circles on the floor of La République. On some days, particularly weekends, other events would have started on the site during the morning: one such event took place on the final day of my research, with representatives of Nuit Debout camps from across France gathering together to discuss strategies. On most days, though, the site was small until the late afternoon. Between around 16:00 and 19:00, the infrastructure of a protest camp was set up in La République. A welcome desk, a main stage, a kitchen, a radio station, a women's only safe space, several book stores and multiple commissions could be found inhabiting La République by 19:00, with a programme of events available at the welcome desk. In my visits - which covered one week in May 2016 and a follow up in September 2016, when the site was significantly smaller - Nuit Debout came to life by the end of this period, acting as a market of ideas, debates and events. As darkness fell the party element of Nuit Debout, centred on the area around the large monument in the middle of La République, started to increase, with music playing. Alcohol was technically prohibited from the site, but several people were wandering selling cans of beer. By around 22:00, many of the smaller commissions would typically finish, as more and more people gathered round the main stage for the speeches, discussions and decision making of the 'general commission'. In darkness, it became harder to float between groups, and commissions or discussion groups tended to get drawn together so that speakers could engage with each other. Through the final two to three hours of Nuit Debout - by the time of my visit, police restrictions meant that formal activities were scheduled to end around midnight, though in practice many people stayed on a little later - the bright lights on the streets surrounding La République contrasted with the darkened square to produce a sort of luminal boundary, separating Nuit Debout out from the rest of the city. In the next three sections, I seek to explore the role of the night in Nuit Debout along three key themes: disruption; conviviality and cover; and presence and visibility.

\section{Disruption}

"We give the entire twenty-four hours a new master schedule, with new ways of connecting one day to the next" (Melbin, 1987p82)

In my two interviews with activists, Nuit Debout's disruption of urban rhythms was cited as a key strength of the movement:

"the main aim wasn't only to occupy the place, it was to disrupt the rhythm, the rhythm that we all follow. You know the protesting, you protest in the day and the 
beginning of the afternoon, and then you go home. We didn't want to do this, we wanted to disrupt the rhythm of the protest"

Movements drawing from occupation strategies have found success in laying claim to a space. These approaches seek to create a permanent occupation of a site, which will disrupt and challenge the strategies of governance within the broader city. By contrast to this very spatial focus of previous movements Nuit Debout, as its name implies, lays claim instead to a period of time, or perhaps to a timespace - La République, during the night (see figure 1). However, while at a specific location, Nuit Debout's disruption is as much about the broader rhythms of the site and city. For police and other state authorities, protesting through the night disrupts what Melbin describes as the master schedule of twenty-four hours, or what Crary describes as the 'orderword' of 24/7 (Crary, 2013). Night may be distinct from the day, but the two are linked together by multiple different rhythms. Police rotas, street cleaning and other all-day systems are disrupted across the full twenty four hour cycle. Late night police shifts cost money, disrupt policing at other times, and create frustration: activists that I spoke to were well aware that the police wanted to go home as much as anyone else. In this manner, protestors use the night to stretch and frustrate attempts to constrain protest by pushing at rhythms of governance, an important technique in the context of France's state of emergency laws that were operating at the time of Nuit Debout. In light of the previously noted crackdown on protest in many locations (Mitchell, 2003), night as a more peripheral space offers the opportunity for this sort of activity. Second, Nuit Debout disrupts the broader rhythms of the city around them. La République is a space of gentrified homes and tourist-oriented businesses, with several chain restaurants located on the square such as McDonald's and Quick Burger. The late night activity has sought to generate attention by disrupting the routines and patterns of these groups who represent, for Nuit Debout activists, either the role of big business in modern France, or a middle class perceived to be associated with state interests. As noted later on, the success of this disruption is debatable, but still, night has offered that opportunity.

Third, and perhaps most interestingly, Nuit Debout disrupts the rhythms of protest itself. Innovation and originality in protest are understood as a key way of overcoming 'protest fatigue' (Woods et al., 2012), and protest camps have long been a way of generating innovation (Feigenbaum et. al., 2013). In the words of the Nuit Debout protestors, they weren't "just going to go home". Rather, the movement has sought to energise activists by offering a fresh challenge. The name 'Nuit Debout' 'night on our feet' or 'standing all the night!' - refers to this energy and self-challenging. Here, the disruption is drawn from as a way of inspiring and reenergising activists, forcing Nuit Debout protestors to come up with fresh ways of working. The preceding Indignados movement has been described as a "laboratory for urban resistance" (Abellán et al., 2012), and Nuit Debout similarly has sought to find new ways of arranging and holding protests. Its key method of doing this has been through 'commissions', each of which was set up to explore certain problems, raise awareness about key issues, or develop strategies for combatting the Loi Travail. Commissions have emerged on a range of issues: from the practical, such as a 'welcoming commission' which organises an information stand on the square and a 'logistics commission' which coordinates the timings of activities; to the thematic, such as the 'ecologies commission' which seeks to discuss issues relating Paris' deprived suburbs and the 'feminists commission' which operates some of its activities in a separately bounded safe-space. Nuit Debout has thus drawn from night to generate a timespace which facilitates the creativity that post-2011 protest movements have required. However, this disruption has also created challenges. Protest and activism require energy; in other words, "Emotion is strategically deployed and fostered by organisers to engender sufficient commitment amongst activist collectives to maintain their on-going participation" (Brown et al., 2009p26). 
Protesting at night has been significantly disruptive to this commitment and participation. As one interviewee told me:

"Sometimes a commission will say we are so tired, we need people to help us. And so the people that stay during the night, maybe they don't have to work during the day. And so that's a problem with the night that it's a disruption of the rhythm so not all the people can follow this rhythm."

Simply put, the disrupted rhythm meant that protesters have struggled to gain new recruits, particularly among those who worked during the week. Regular attendees became tired, with nightly protests taking their mental and physical toll. Night-shifts are known to create a number of psychological, biological and social challenges, producing stresses on the body and how we relate to others, particularly those close to us (Wagstaff et al., 2011). Nuit Debout's nocturnality highlights how such stresses can cross over into protest. Melbin equates the work of people on the night-shift to that of people who travel long distances for work - in his work, he argued that the families of shift workers often have to absorb the challenges of the night shift by taking on extra domestic work and through the emotional strain of losing contact time as a family (Melbin, 1987). In the context of protest movements, problems of fatigue, strains on family life and other emotional challenges are recurring issues (as highlighted in relation to the previously discussed Greenham Common camps in Harford \& Hopkins, 1984; or discussed more generally in Jasper, 2011). For Nuit Debout, the choice to operate primarily at night probably enhanced this, and may reflect a wider difficulty of any innovative form of protest.

Nuit Debout has not been independent of the multiple other temporalities that circulate in the city beyond the diurnal rhythms of day and night. Particularly after the initial few weeks, weekend protests were busier, as well as having a notably larger intersection with people attending La République for or as part of the entertainment in the night-time economy. As noted previously, these challenges may have contributed to the gradual transformation of Nuit Debout, with regular nightly events coming to an end through the summer and early autumn of 2016. In later months, nights were given over to specific commissions, thus allowing for a rolling programme of protests of different sizes and scales, with weekends reserved for bigger gatherings. The final regular nocturnal protests in Paris took place in autumn 2016, in part reflecting this protestor fatigue. As of 2017, Nuit Debout continues to operate with occasional meetings in both day and night. In seeking to challenge themselves, Nuit Debout's protestors have generated fresh ideas and fresh ways of working - of the people I spoke to casually at the site, many were clearly invigorated by Nuit Debout. In so doing, however, this act has also proved to limit the amount of people who can be involved, and potentially the length of time for which participants can be active.

\section{Cover and Conviviality}

"Sometimes there are people breaking things. And if they want to, then the night gives more opportunities for that"

"it is a meeting place, a continual meeting place. Because it makes networks, you take that guy who was so fun the other night, or that girl who was so fun the other night, you meet people from different origins, now you are making networks"

Nuit Debout seeks to "offer to all a space for discussion, debate and for collective decisions". ' Like other protest camps, such as Occupy and Indignados, Nuit Debout has made the creation and imagination of new forms of convivial democracy a core aim (Feigenbaum et al., 2013) and as noted 
above the nocturnality has contributed to this by disrupting rhythms and routines of the norm, but at a cost. Night also facilitates the conviviality of the space. Here, 'conviviality' can be understood as "conceived accommodation of difference" (Hinchliffe et al., 2006p124), in which there is an attempt to generate politics out of hearing and courting this difference. We have already seen how the sociorhythmic night contributes to the aims of Nuit Debout, but the inherent darkness, or rather shifted interplay of light and dark, of the night time city has also been used in constructing this time-space for debate. As phenomenologists have argued (e.g.Merleau-Ponty, 1962p.283), in darkness we are much less sure of ourselves. Malinowski expands on Merleau-Ponty's claim, saying that darkness:

"does not spread out before me but touches me directly, envelops me, embraces me, even penetrates me, completely, passes through me, so that one could almost say that while the ego is permeable by darkness it is not permeable by light. The ego does not affirm itself in relation to darkness but becomes confused by it" (Minkowski, 1970p.429)

If the 'self' is understood and made more secure by our ability to see, identify and define ourselves in relation to 'Other', then at night we lose some of this capacity. Darkness penetrates the self, removing the protective bubble of vision and rendering us to be more 'open'. At the same time, it also renders Others less visible, protected from the surveillance of the day by darkness. Even with artificial lighting, the city at night retains shadows, spaces hidden by glare, and moments or locations which are much less visible than in natural light (Edensor, 2015). The result is that we are more open to sensations, ideas, feelings, affects and other stimuli: we do not have the same closed-off bordered and protected bubble around us, but are instead able to interact with the materials and people that we encounter. As Wilson notes, this encountering plays a key role in the politics of protest: it is part of what is at stake when "crowds, occupations and social movements are formed and assembled in urban spaces" (Wilson, 2016p7). Simply put, then, people are more open to each other in the darkness, more convivial (Melbin, 1987). This intersects with the social rhythms that have previously been discussed, as night is recognised as a time for play, outside of the routines and rhythms of everyday life. These have come together to facilitate the conviviality of Nuit Debout.

Clearly, la République is not in complete darkness during the night; as well as the astronomical cycle of lighter and darker nights through the year, the space is of course subject to various forms of artificial lighting. The central square is surrounded by shops and businesses which, in combination with street lighting, provided a bright background. Various commissions also light their own operations (see figure 2), powered by generators that were brought to the site. The combined effect of the bright background and the pockets of light on la République was often to dazzle, obscuring faces in the foreground. In my time at Nuit Debout, I found that it would often be possible to see speakers or groups of people across the square, but not see the composition or members of a group seated nearby. This had several different effects. On the one hand, as darkness fell, groups had to come closer together in order for interaction to happen. Participants were more likely to sit down in order to see each other on the same level, and to focus more clearly on the words that were spoken. Chance interactions between those attending the site became more prevalent at night as well people asking for directions, or joining groups out of curiosity because they could not see from a distance what the group was about; I noted many more people stopping to linger near speakers after dark. Certainly, the largest and more stable crowds gathered after darkness had fallen, whereas in the late evening light, people were more likely to wander around la République's edge. During the Friday night I attended, where alcohol consumption fuelled the conviviality of night, people more quickly started to chat, dance and sing as the night went. The nocturnality of Nuit Debout thus helped generate the sort of site of political debate that the protestors had sought out. 
However, this inability to see those relatively close and the dazzling effect of lighting has had some negative consequences. Interview participants told me that, particularly in the early days of Nuit Debout, there were several cases of sexual assault and harassment. Similar reports had previously come from several of the Indignados and Occupy sites (Feigenbaum et al., 2013; Pickerill et al., 2012). Nuit Debout has seemed to respond quickly to these issues, with a commission for safety created and the feminist commission growing in size. Equally, online reports of misogyny and harassment continue. One failing of Nuit Debout, perhaps, is to recognise that - despite being an open public space - the fragmentation of the square, the pockets of darkness and shadows and the rather isolated nature of different activities can enhance the negative elements of nocturnality that increase both fear and danger that women face of sexual harassment (Valentine, 1989; Wesely et al., 2004).

As well as generating the possibility of increased harassment for women, the darkness of the nighttime city also facilitated violence among the protests. Nuit Debout has been at pains to describe itself as a non-violent movement, but as with many movements there have been people attending the site who are willing to use violent techniques to disrupt, or who have simply attended to take advantage of the cover of both the protest and darkness. Through participant observation, it became apparent that there was a tension between Nuit Debout's openness towards people attending, and a lack of capacity among any of those in the movement to restrict how people used La République. The strength of Nuit Debout came from its qualities as a gathering of people in public space - the gathering of bodies that Butler (2015) discusses - and as such there was no group within Nuit Debout that could prevent anyone using the site, whether for drinking, partying, sexual harassment or violent forms of direct action. While commissions could control who used their facilities or who were speakers within their space, there was no overall control of the movement. At the time of my visit, a nightly police presence monitored entrance to the square, though only lightly. In the extended interviews that I carried out, protesters said that police were inconsistent in their approach: sometimes they would quickly intervene where violence or other law-breaking, such as starting fires, was apparent; in other cases they would overlook this. Protestors themselves sometimes reported such activities to the police, seeking to strike a balance between wanting to continue to attract as many as possible to the protests, while recognising that significant law breaking would lead to forceful police intervention. Regardless of the challenges created by darkness, however, the protestors saw benefits to the cover of darkness as well. The advantages of hindering attempts to identify and limit participants were there, and this is a feature of the night long used by those who have wanted to avoid state surveillance (Beaumont, 2015; Schivelbusch, 1988). Indeed, one interviewee expressed a slight frustration that as a site, la République remained too open, with a limited number of access and exit routes.

In many ways then, this element of the movement has built upon the different atmospheres that pervade the city at night. While clearly immaterial and 'of the air', atmospheres also have what Anderson (2014) describes as a "strange materiality" (p.140). Atmospheres are thus "a kind of indeterminate affective excess through which intensive space-times are created and come to envelop specific bodies: sites, objects, people and so on" (p.160). In the night time city, dark and light interplay in complex ways which involve the intersection of bodies, materials and affects (Edensor, 2012a). In turn, the users of the night-time city, free from work and more likely to be engaged in leisure activities, are more open to this nocturnal atmosphere of conviviality. As such, for Nuit Debout, the atmospheres of conviviality and the cover of darkness that are found in the night have offered both advantages and disadvantages. On the one hand, night has been a resource for starting conversation and fostering interaction; on the other, night remains a space of potential, danger and harassment, with women at greater risk of this than men. While Nuit Debout has made 
some steps to overcome this challenge, like the other occupation movements since 2011 there are clear gaps in its ability to do so.

\section{Presence and Visibility}

Returning to Butler, the act of gathering in public squares and at protest movements is an act of declaring the self as present, as part of the public: "the people are not a given population, but rather constituted by the lines of demarcation that we implicitly or explicitly establish" (Butler, 2015p.4). The act of putting oneself in a prominent position and occupying it for a period of time is an act of claiming to be part of 'the people'. The literature produced by Nuit Debout shows a clear desire to make this sort of claim. The headline text on Nuit Debout's daily bulletin emphasises that participants are "reappropriating for themselves public speech and public space. Neither heard, not represented, people of all backgrounds are welcome to think about the future of our world. ${ }^{\text {ii }} A$ statement in the nightly coordination report from the $100^{\text {th }}$ night of Nuit Debout similarly reflects on the role of presence: "Here at la République and in several other places, we stoke the fires of intelligence, imagination, political analysis, braveness, and the pleasure of being together".iii Throughout the discourse developed by Nuit Debout, there has been an emphasis on the ways in which the protest is about being present in public space, and how this might drive political debate. A core aim of the movement has been to repeat the success of those before it by bringing a range of people together into public space. To that end, Nuit Debout in Paris has been active in attempting to reach the populations of the banlieues, Paris's comparatively poor and ethnically diverse suburbs. The success of this has been varied: the presence of anti-colonial and pan-African commissions as part of Nuit Debout (figure 3) illustrates some success in this area, but there remains a clear limitation to the demographics of those who have been participating in Nuit Debout.

As a nocturnal activity, this role of presence is interesting in three ways. First, being present at night remains a relatively unusual activity: night-time cities are quieter than day-time cities, despite increased parity between the two (Beaumont, 2015). The Occupy movement in particular gained press attention for the nocturnal elements of its occupation, and Nuit Debout's focus on the night has enhanced this - in other words, the simple fact of it being Nuit Debout has attracted attention and helped the movement. Second, however, the night has created limitations on the diversity of the crowd, as already noted. This has limited Nuit Debout's capacity to get such a wide number of bodies together, and has contributed to its declining numbers as the protests have run on. Third, being present on a nightly basis has created an interesting rhythm to the protest. While still disrupting the city and making claims over space, Nuit Debout had by my visit in May also become a part of the cityscape, a reoccurring event through which people might pass, whether by chance, or to observe, to question or to participate. Here, it has been the intersection of the nocturnality and the rhythmicity of Nuit Debout that has started to make the protests at part of the background of Parisian life. Although this regularity threatens the creativity of Nuit Debout, it may also mark some success in showing how public assembling can still result in political discourse (see Amin, 2008).

This assembling, however, was not always visible:

"I arrive in Paris on the first hot day of Spring. The walk to the hotel, just off the Place de le République, is hot and tiring. I see signs of graffiti on shops and stores as I approach the square. When I enter, there's not much there: the only major signs of Nuit Debout's presence is the central statue. Covered in multicoloured political slogans, it looks at this time of day $(3 \mathrm{pm})$ more like an art installation. The metro exit is shut, and on closer inspection the floor is smattered with washed out political slogans, while cigarette butts lie around the bottom of trees. Still, on the 
bright sunny day, there's not a lot here, and I head to my hotel to get some sleep."

"(Morning, around 9am): Traces of the event. Text on the ground, posters on the street light. A small police presence remains, looking a bit lost without an event to govern. Confused tourists stare at the closed metro entrance."

My notes from my first visit to Nuit Debout reveal the lack of visibility that Nuit Debout had in daytime Paris (figure 4). By occupying one square in Paris - albeit an extremely high profile one Nuit Debout already limits itself. Pushing further, however, Nuit Debout is rendered totally absent in the city itself for many hours of the day. Even when setting up in the afternoon, the full extent of the site and of the scale of protests is not visible until later on in the day. Nuit Debout has combatted this lack of visibility with its production of a range of media. As well as standard social media and web activities, activists from Nuit Debout have also produced a wider range of media, including podcasts, printed bulletin newsletters, a series of leaflets and material describing their cause, and other promotional material. Still, while creating some localised disruption at night, Nuit Debout during the day has been absent from the city. With regards to being present and visible, then, the night has been helped Nuit Debout to appear distinct and attract attention, and as such protestors have found a timespace that they have able to claim in order to participate in public discourse. However, the very capacity to claim this space exists because of it is a peripheral timespace - and as such, to protest at night is to render oneself partially invisible from those who only use the city during the day.

\section{Nuit Debout, Night in Protest Movements and the Margins of the City}

Since 2011, we have seen a new phase of global activism through the spread of a series of protest camp movements. These movements have shown evidence of an iterative learning process in which new techniques of protest and communication have been passed from site to site. Notably, as well as showing innovation in ways of contesting power, these sites have also produce new infrastructures for living and inhabiting spaces of protest, and for communicating and spreading messages out from these sites (Feigenbaum et al., 2013). Perhaps it is not surprising that these have emerged amidst techniques of control and governance that have sought to erode rights of assembly and protest in cities over the last twenty years. By consolidating protest in sites that are both visible, through these communication practices, and relatively solid, through the infrastructures that are laid down, protest camps have been able to make claim over particular spaces. These restrictions have pushed protestors away from timespaces of power and towards sites that are, in various ways, peripheral. For the Nuit Debout protestors at La République, night has played that peripheral role, allowing them to gather and protest in a way that may not have been possible in such a central space during the day. Nuit Debout has drawn from the experiences and knowledges developed by nocturnal protesting in these movements, that is, the Arab Spring, Indignados and Occupy, but developed them in its own.

Where Nuit Debout has differed is in its daily routine of establishment and reestablishment, relying on night and its peripheral qualities as a way of offering stability and protection, rather than solely relying on infrastructural forms. Nuit Debout thus highlights the way that night has functioned for multiple protest movements, as an intensive timespace in which political debate, discourse and protest might be more possible. Rhythm and darkness - the socio-rhythmic night and the biogeoastronomical night working together - designate the night as typically outside of normal spaces of protest, mass gathering and other activities. These features of night create a timespace in 
which social interactions are more fluid, more open and more radical. In Nuit Debout, these conditions have allowed protestors to carve out their own urban sphere. Potentially, by avoiding protest in day, Nuit Debout has identified an approach that may contribute to its longevity, despite challenges of fatigue. This paper has identified three ways in which night has functioned for Nuit Debout - as disruption; cover and conviviality; presence and visibility. However, operating at night has produced significant challenges. While the cover of darkness makes monitoring more difficult for the state, it also does this for protestors. Problems of sexual harassment and violence are testament to this. While activism will often contain a certain amount of partying and celebration, some people within the night-time city were drawn to La République more for this than to contribute to Nuit Debout. The disruption that nocturnal protests brought to the city was also absorbed into protestors' daily lives, and this quickly contributed to problems of protest fatigue. Finally, the visibility of protesting at an unexpected time has been offset by the lost visibility of not being present in the morning, when many people use the city.

In understanding urban protests, recognising that the city and the timespaces inhabited by the protestors are active constituents in the nature of the protest and its impact is an important move, and one that geographers have pushed us towards. In this paper, the relatively unexplored temporality of protest and specifically the role of night helps provide a clearer understanding of how post-2011 protest camps generally and Nuit Debout in particular have created timespaces for the imagining of new forms of political action. Night is a timespace into which people looking for activity outside of state surveillance have long been displaced. With improved telecommunications, it is now possible to draw from this benefit of night while also attempting to be more broadly visible. With the restriction of the capacity of protestors to participate actively in public space during the day, there has been further need to move to the night as a timespace for protest, despite the challenges that it presents.

\section{Figure captions}

Figure 1: The Nuit Debout protests

Figure 2: An example of temporary lighting on the square

Figure 3: A banner of the African commission

Figure 4: A quiet Place de la République during the day

Abellán, J., Sequera, J., \& Janoschka, M. (2012). Occupying the \#Hotelmadrid: A Laboratory for Urban Resistance. Social Movement Studies, 11, 320-326.

Amin, A. (2008). Collective culture and urban public space. City, 12, 5-24.

Baldwin, P. C. (2012). In the Watches of the Night. Chicago: Unviersity of Chicago Press.

Beaumont, M. (2015). Night Walking. London: Verso.

Bolton, M., Froese, S., \& Jeffrey, A. (2016). "Go get a job right after you take a bath": Occupy Wall Street as Matter Out of Place. Antipode, 48, 857-876.

Brown, G., \& Pickerill, J. (2009). Space for emotion in the spaces of activism. Emotion, Space and Society, 2, 24-35. 
Butler, J. (2015). Notes toward a performative theory of assembly. Cambridge, MA: Harvard University Press.

Castree, N. (2009). The Spatio-temporality of Capitalism. Time \& Society, 18, 26-61.

Crary, J. (2013). 24/7. Los Angeles: Verso.

Cresswell, T. (1994). Putting women in their place: the carnival at Greenham Common. Antipode, 26, 35-58.

Dow, B. J., \& Wood, J. T. (2014). Repeating History and Learning From It: What Can SlutWalks Teach Us About Feminism? Women's Studies in Communication, 37, 22-43.

Dworkin, A. (1993). Letters from a War Zone. New York: Lawrence Hill Books.

Edensor, T. (2012a). Illuminated atmospheres: anticipating and reproducing the flow of affective experience in Blackpool. Environment and Planning D: Society and Space, 30, 1103-1122.

Edensor, T. (2012b). Introduction: Thinking about Space and Rhythm. In T. Edensor (Ed.), Geographies of rhythm: nature, place, mobilities and bodies (pp. 1-18). Ashford: Ashgate Publishing, Ltd.

Edensor, T. (2013). Reconnecting with darkness: gloomy landscapes, lightless places. Social \& Cultural Geography, 14, 446-465.

Edensor, T. (2015). The gloomy city: rethinking the relationship between light and dark. Urban Studies, 52, 422-438.

Feigenbaum, A., Frenzel, F., \& McCurdy, P. (2013). Protest Camps. London: Zed Books.

Foucault, M. (1982). The Subject and Power. Critical Inquiry, 8, 777-795.

Graeber, D. (2009). Direct action: An ethnography: AK press.

Green, J., Perkins, C., Steinbach, R., \& Edwards, P. (2015). Reduced street lighting at night and health: A rapid appraisal of public views in England and Wales. Health \& Place, 34, 171-180.

Gwiazdzinski, L. (2005). La Nuit, Dernière Frontière de la Ville [The Night: Final Frontier of the City]. La Tour-d'Aigues: Editions de l'Aube.

Halvorsen, S. (2012). Beyond the Network? Occupy London and the Global Movement. Social Movement Studies, 11, 427-433.

Halvorsen, S. (2015). Taking Space: Moments of Rupture and Everyday Life in Occupy London. Antipode, 47, 401-417.

Harford, B., \& Hopkins, S. (1984). Greenham Common: Women at the wire: Women's Press (UK).

Hinchliffe, S., \& Whatmore, S. (2006). Living cities: Towards a politics of conviviality. Science as Culture, 15, 123-138.

Hubbard, P., \& Colosi, R. (2015). Taking back the night? Gender and the contestation of sexual entertainment in England and Wales. Urban Studies, 52, 589-605.

Jasper, J. M. (2011). Emotions and social movements: Twenty years of theory and research. Annual review of sociology, 37, 285-303.

Junor, B. (1995). Greenham Common women's peace camp: a history of non-violent resistance 19841995: Working Press.

Juris, J. S. (2012). Reflections on Occupy Everywhere: Social media, public space, and emerging logics of aggregation. American Ethnologist, 39, 259-279.

Lefebvre, H. (2004). Rhythmanalysis: Space, Time and Everyday Life. London: Continuum.

Mackay, F. (2014). Mapping the Routes: An exploration of charges of racism made against the 1970s UK Reclaim the Night marches. Women's Studies International Forum, 44, 46-54.

Massey, D. (1995). Thinking Radical Democracy Spatially. Environment and Planning D: Society and Space, 13, 283-288.

Melbin, M. (1987). Night as Frontier: Colonizing The World After Dark. New York: The Free Press.

Merleau-Ponty, M. (1962). The Phenomenology of Perception. London: Routledge.

Minkowski, E. (1970). Lived Time. Evanston: Northwestern University Press.

Mitchell, D. (2003). The right to the city: Social justice and the fight for public space: Guilford Press.

Mitchell, D. (2016). The liberalization of free speech: Or, how protest in public space is silenced. Spaces of Contention: Spatialities and Social Movements, 47. 
Morris, N. J. (2011). Night walking: darkness and sensory perception in a night-time landscape installation. Cultural Geographies, 18, 315-342.

Pickerill, J., \& Chatterton, P. (2006). Notes towards autonomous geographies: creation, resistance and self-management as survival tactics. Progress in Human Geography, 30, 730-746.

Pickerill, J., \& Krinsky, J. (2012). Why does Occupy matter? Social Movement Studies, 11, 279-287.

Roberts, J. M. (2008). Public spaces of dissent. Sociology Compass, 2, 654-674.

Routledge, P. (2000). Our resistance will be as transnational as capital': Convergence space and strategy in globalising resistance. GeoJournal, 52, 25-33.

Schivelbusch, W. (1988). Disenchanted Night. Oxford: Berg Publishers.

Schlör, J. (1998). Nights in the Big City: Paris, Berlin, London 1840-1930. London: Reaktion.

Shaw, R. (2015). Controlling darkness: self, dark and the domestic night. Cultural Geographies, 22, 585-600.

Smith, N. (2002). New globalism, new urbanism: gentrification as global urban strategy. Antipode, 34, 427-450.

Uysal, Ü. E. (2012). An urban social movement challenging urban regeneration: The case of Sulukule, Istanbul. Cities, 29, 12-22.

Valentine, G. (1989). The geography of women's fear. Area, 21, 385-390.

Wagstaff, A. S., \& Lie, J.-A. S. (2011). Shift and night work and long working hours - a systematic review of safety implications. Scandinavian Journal of Work, Environment \& Health, 37, 173185.

Wesely, J. K., \& Gaarder, E. (2004). The gendered "nature" of the urban outdoors women negotiating fear of violence. Gender \& Society, 18, 645-663.

Wilson, H. F. (2016). On geography and encounter: Bodies, borders, and difference. Progress in Human Geography.

Woods, M., Anderson, J., Guilbert, S., \& Watkin, S. (2012). 'The country (side) is angry': emotion and explanation in protest mobilization. Social \& Cultural Geography, 13, 567-585.

\footnotetext{
' Démocratie sur la Place, https://nuitdebout.fr/paris/commissions/dslp/ Accessed 8th August 2016. All translations from French, including any inevitable errors, are the author's own

ii Nuit Debout Bulletin 66-67 Mars, ( $5^{\text {th }}$ May, 2016)

iii Assemblée Rétrospective et de Coordination \#100mars, (8th June, 2016) Accessed 8th August 2016

https://nuitdebout.fr/paris/2016/06/08/compte-rendu-de-lassemblee-de-retrospective-et-de-coordination100-mars-8-juin/
} 